\title{
Blind spots in medical students with color vision deficiency
}

This article was published in the following Dove Press journal:

Clinical Ophthalmology

\author{
Soma Farag \\ Medical Department at Imperial \\ College London University, South \\ Kensington, London, UK
}

\section{Dear editor}

The cross-sectional descriptive study on color vision deficiency (CVD) among biomedical students carried out by Dohvoma et $\mathrm{al}^{1}$ is an interesting read. CVD is not tested in medical students in the UK, though it is routinely tested among those in India upon admission, ${ }^{2}$ as it is believed that misinterpretation of colored signs can lead to misdiagnosis. In the aforementioned study, $1.3 \%$ of the biomedical students were positively tested to be "color blind" through Ishihara's plate test and Roth's 28 hue test. ${ }^{1}$ The Farnsworth-Munsell 100 hue test also exists to diagnose CVD, though this is more time-consuming and expensive to carry out than Roth's 28 hue test. ${ }^{3}$

The authors correctly highlight the importance of detection of medical signs based on color such as jaundice, rashes, and interpretation of laboratory photographs. CVD affects 1 in 12 men and 1 in 200 women; ${ }^{4}$ given the low prevalence of this, particularly among females, one can argue that it would be a waste of resources to routinely test medical students on entry or perhaps limiting the test to males, whom CVD affects more. Furthermore, literature shows that the prevalence of CVD among male medical students and the general population is similar. ${ }^{5}$ Therefore, if medical students are tested for CVD, then testing could be expanded to other professions that also rely heavily on color accuracy, such as pilots and electricians.

One could even argue that testing medical students for CVD is a waste of resources, as there is little published literature to provide evidence that CVD affects the performance of doctors. ${ }^{5}$ Additionally, there are many leads in the diagnosis ${ }^{5}$ pathway of a patient that do not necessarily always rely on color detection, for example, history taking, and practitioners with CVD could ask for the second opinion of colleagues on detection of conditions with distinctive color such as pallor and erythema.

\section{Disclosure}

The author reports no conflicts of interest in this communication.

\section{References}

1. Dohvoma VA, Ebana Mvogo SR, Kagmeni G, et al. Color vision deficiency among biomedical students: a cross-sectional study. Clin Ophthalmol. 2018;12:1121-1124.

2. Dhingra R, Rohatgi J, Dhaliwal U. Preparing medical students with congenital colour vision deficiency for safe practice. Natl Med J India. 2017;30(1):30-35.

3. Erb C, Adler M, Stübiger N, et al. Colour vision in normal subjects tested by the colour arrangement test 'Roth 28-hue desaturated'. Vision Res. 1998;38(21):3467-3471.

4. Tidy C. Colour VisionDeficiency. Available from: https://patient.info/health/colour-vision-deficiencycolour-blindness. Accessed June 27, 2018.

5. Spalding JA. Colour vision deficiency in the medical profession. Br J Gen Pract. 1999;49(443):469-475.
Medical Department at Imperial College London University, Kensington, London SW7 2AZ, UK

Emailsf30I5@ic.ac.uk
Clinical Ophthalmology 2018:12 I875-1876

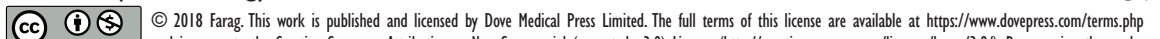

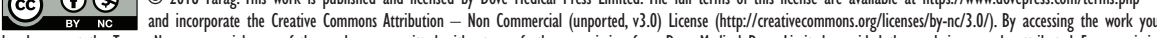
hereby accept the Terms. Non-commercial uses of the work are permitted without any further permisision from Dove Medical Press Limited, provided the work is properly attributed. For permission for commercial use of this work, please see paragraphs 4.2 and 5 of our Terms (htpps://www.dovepress.com/terms.php). 
Dove Medical Press encourages responsible, free and frank academic debate. The content of the Clinical Ophthalmology 'letters to the editor' section does not necessarily represent the views of Dove Medical Press, its officers, agents, employees, related entities or the Clinical Ophthalmology editors. While all reasonable steps have been taken to confirm the content of each letter, Dove Medical Press accepts no liability in respect of the content of any letter, nor is it responsible for the content and accuracy of any letter to the editor.

Clinical Ophthalmology

\section{Publish your work in this journal}

Clinical Ophthalmology is an international, peer-reviewed journal covering all subspecialties within ophthalmology. Key topics include: Optometry; Visual science; Pharmacology and drug therapy in eye diseases; Basic Sciences; Primary and Secondary eye care; Patient Safety and Quality of Care Improvements. This journal is indexed on

\section{Dovepress}

PubMed Central and CAS, and is the official journal of The Society of Clinical Ophthalmology (SCO). The manuscript management system is completely online and includes a very quick and fair peer-review system, which is all easy to use. Visit http://www.dovepress.com/ testimonials.php to read real quotes from published authors. 